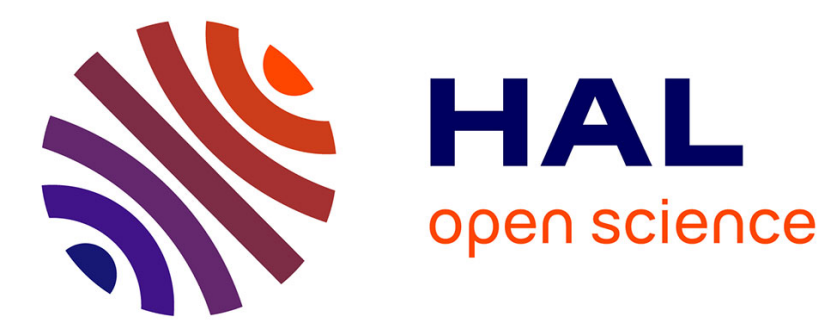

\title{
Modelling coarse woody debris in Pinus spp. plantations. A case study in Northern Spain
}

Celia Herrero, Valentín Pando, Felipe Bravo

\section{To cite this version:}

Celia Herrero, Valentín Pando, Felipe Bravo. Modelling coarse woody debris in Pinus spp. plantations. A case study in Northern Spain. Annals of Forest Science, 2010, 67 (7), 10.1051/forest/2010033 . hal00883572

\section{HAL Id: hal-00883572 \\ https://hal.science/hal-00883572}

Submitted on 1 Jan 2010

HAL is a multi-disciplinary open access archive for the deposit and dissemination of scientific research documents, whether they are published or not. The documents may come from teaching and research institutions in France or abroad, or from public or private research centers.
L'archive ouverte pluridisciplinaire HAL, est destinée au dépôt et à la diffusion de documents scientifiques de niveau recherche, publiés ou non, émanant des établissements d'enseignement et de recherche français ou étrangers, des laboratoires publics ou privés. 


\title{
Modelling coarse woody debris in Pinus spp. plantations. A case study in Northern Spain
}

\author{
Celia Herrero*, Valentín PANDo, Felipe Bravo \\ Sustainable Forest Management Research Institute UVa.INIA, ETS Ingenierías Agrarias, University of Valladolid, \\ Avda. de Madrid, 44, 34004, Palencia, Spain
}

(Received 18 April 2009; accepted 21 January 2010)

Keywords:
CWD /
snag /
log /
logistic /
pine

Keywords:

snag /

$\log /$

pine

\begin{abstract}
- Coarse woody debris (CWD) plays a substantial role in several ecological processes in forest ecosystems, providing a habitat for many organisms and participating in biogeochemical fluxes. Understanding CWD dynamics is important to classify adequate density, size and amount into different decay classes and to make decisions that include biodiversity and the carbon budget in practical forestry.

- A two-step model has been developed to quantify CWD in Pinus spp. plantations in Northern Spain. The two-step approach was composed of a logistic model to predict the probability of CWD occurrence and linear models to quantify the two components considered, basal area of snags and volume of logs.

- Site conditions, and climatic and stand variables were included in the models as independent variables. Good performance of the two-step model $\left(R^{2} \operatorname{snag}=39.9 \%, R^{2} \log =62.8 \%\right)$ was observed.

- Modelling CWD is a useful tool for simulating future scenarios in the current context of climate change. Models inform stakeholders properly about defining the best silvicultural options for the distribution of CWD under sustainable forest management.
\end{abstract}

\section{INTRODUCTION}

Dead wood plays an important role in the ecological processes of forest ecosystems. Although it is recognised that logs and snags are important components of forest dynamics linked to biodiversity (Harmon et al., 1986; McComn and Lindenmayer, 1999), little is known about dead wood dynamics in Mediterranean forests, where factors such as biodiversity conservation and carbon sequestration are of great importance.

Coarse woody debris (CWD) contributes to the total amount of organic matter in the forest soil, thereby affecting energy flow (McComn and Lindenmayer, 1999), soil development and nutrient cycles (Harmon and Chen, 1991; Harmon et al., 1986). Furthermore, dead wood is considered as a substratum for many processes, such as humification, nursery sitting for seedling establishment (Köster et al., 2005) and structural habitat features for a wide variety of micro-organisms, vascular and non-vascular plants, and animals (Harmon et al., 1986).

In managed forests, under sustainable wood production, dead trees are minimised to avoid pest problems and hazards. Thus, trees killed by insects, diseases and fire are commonly harvested immediately if economics and accessibility allow. By enhancing the presence of dead wood in managed forests,

\footnotetext{
* Corresponding author: chdeaza@pvs.uva.es
}

managers try to respond to the increasing societal demands on biodiversity and carbon pool services.

According to Spies et al. (1988) and Harmon and Chen (1991), CWD and its relative contribution to total ecosystem biomass varies greatly in the landscape, depending on forest types, disturbance regimes, topography and stand characteristics. CWD dynamics studies show that it depends on the competition index (Barclay and Layton, 1990), forest type, forest age (Spies et al., 1988), successional stage, species, standing volume, management practices (Linder et al., 1997; Siitonen et al., 2000), climate characteristics (Harmon et al., 1986; Linder et al., 1997), site conditions, such as exposure or slope (Linder et al., 1997), physical and chemical agents (Montes and Cañellas, 2006), the activity of decaying organisms (Linder et al., 1997), and natural and human disturbances (Krankina et al., 2001; Siitonen et al., 2000).

Different CWD dynamics models have predicted the general rate of fall and decay of snags and logs over several years: i.e., the dynamics of snags and logs over time (Brin et al., 2008; Mellen and Ager, 2002). However, the possibility of predicting the presence or absence of CWD by means of forest characteristics has not been sufficiently studied. Binary events, such as the presence of structural features in the stands (logs, snags, etc.), ingrowth and natural non-catastrophic mortality, show a high stochasticity and are key components in long-term forest forecast systems. A two-step model method, suggested 
Table I. Main database characteristics used to develop the CWD models in the studied Pinus spp. plantations in Northern Spain.

\begin{tabular}{|c|c|c|c|c|}
\hline & Mean & Minimum & Maximum & Standard deviation \\
\hline \multicolumn{5}{|l|}{ Pinus spp. stands ( $\mathrm{n}=66$ plots) } \\
\hline QMD (cm) & 22.2 & 13.2 & 58.3 & 6.3 \\
\hline$H_{\mathrm{o}}(\mathrm{m})$ & 10.6 & 4.5 & 16.7 & 2.7 \\
\hline$N$ (trees/ha) & 803 & 26 & 1585 & 344 \\
\hline $\mathrm{BA}\left(\mathrm{m}^{2} / \mathrm{ha}\right)$ & 23.2 & 5.6 & 39.3 & 8.3 \\
\hline Altitude ( $\mathrm{m}$ asl) & 973 & 800 & 1100 & 81 \\
\hline $\mathrm{pH}$ & 5.4 & 4.1 & 6.4 & 0.6 \\
\hline Rainfall (mm) & 688 & 518 & 944 & 118 \\
\hline$R_{\text {June }}(\mathrm{mm})$ & 50 & 43 & 59 & 3 \\
\hline$R_{\text {July }}(\mathrm{mm})$ & 27 & 23 & 32 & 2 \\
\hline$R_{\text {August }}(\mathrm{mm})$ & 25 & 20 & 28 & 2 \\
\hline $\operatorname{MinT}\left({ }^{\circ} \mathrm{C}\right)$ & 3.8 & 2.8 & 4.7 & 0.5 \\
\hline MeanT $\left({ }^{\circ} \mathrm{C}\right)$ & 9.9 & 9.0 & 11.0 & 0.5 \\
\hline $\operatorname{MaxT}\left({ }^{\circ} \mathrm{C}\right)$ & 16.0 & 15.0 & 17.4 & 0.5 \\
\hline Radiation $\left(10 \mathrm{~kJ} /\left(\mathrm{m}^{2} \cdot\right.\right.$ day $\left.\mu \mathrm{m}\right)$ & 2045 & 2027 & 2111 & 15.1 \\
\hline $\mathrm{BA}_{\text {snags }}\left(\mathrm{m}^{2} / \mathrm{ha}\right)$ & 0.2 & 0 & 1.2 & 0.3 \\
\hline $\mathrm{V}_{\operatorname{logs}}\left(\mathrm{m}^{3} / \mathrm{ha}\right)$ & 1.5 & 0 & 5.9 & 1.9 \\
\hline
\end{tabular}

QMD: Quadratic mean diameter in $\mathrm{cm}, H_{\mathrm{o}}$ : dominant height in $\mathrm{m}, N$ : trees per ha, BA: stand basal area in $\mathrm{m}^{2} /$ ha, Altitude in $\mathrm{m}$ asl, $R_{\mathrm{June}}, R_{\mathrm{July}}$ and $R_{\text {August }}$ are rainfall for the months of June, July and August, in $\mathrm{mm}$, MinT, Mean $T$ and $\operatorname{Max} T$ are minimum, mean and maximum temperature in ${ }^{\circ} \mathrm{C}$, BA $_{\text {snags }}$ : basal area of snags in $\mathrm{m}^{2} /$ ha and $\mathrm{V}_{\operatorname{logs}}$ : volume of $\operatorname{logs}$ in $\mathrm{m}^{3} / \mathrm{ha}$.

by Woollons (1998), has been used successfully in cases such as the probability of mortality or survival (Bravo and Montero, 2001; Woollons, 1998), or ingrowth (Bravo et al., 2008). This method is similar to one frequently applied in Decision Theory (Hamilton and Brickell, 1983). Data from permanent sample plots frequently show that a relatively large part of the plots have no occurrences of the event even over periods of several years. This means that if all plots are included in model development it would probably be difficult to select an adequate set of significant variables. In addition, statistical problems due to the binomial nature of the event would be present. In contrast, if only plots where the event occurred are used in the model, it may overestimate the event rate for a large-scale forestry scenario (Eid and Oyen, 2003). The two-step model method is tested as a way of resolving specific problems in binary event modelling.

The objective of this study is to develop a snag and log abundance model for Mediterranean pine plantations, composed of Scots pine (Pinus sylvestris L.), Maritime pine (Pinus pinaster Ait.) and Black pine (Pinus nigra Arn.) in Northern Spain, through a two-step approach. The results of this empirical study can provide better knowledge of the dynamics of snags and logs in Mediterranean forest ecosystems.

\section{MATERIALS AND METHODS}

\subsection{Study area}

The study area (186642 ha) is located in Northern Spain (Fig. 1. The altitude ranges from 800 to $1000 \mathrm{~m}$ asl. The climate is Mediterranean, with a long, cold winter and a warm, dry summer. January temperatures range between $-2{ }^{\circ} \mathrm{C}$ and $6{ }^{\circ} \mathrm{C}$, July temperatures between $9{ }^{\circ} \mathrm{C}$ and $21{ }^{\circ} \mathrm{C}$, and mean annual rainfall is $630 \mathrm{~mm}$. Forests cover 61570.5 ha (33\% of the total area). The main natural forest types are dominated by Pyrenean oak (Quercus pyrenaica Willd.), holm oak (Quercus ilex L.) and small-leafed oak (Quercus faginea Lam.). However, as a result of an extensive pine plantation programme carried out mostly during the 1960s, Pinus spp. stands cover $41.5 \%$ of the total forest area. The three main species used in plantations are Scots pine (P. sylvestris L.) (43.6\%), Black pine (P. nigra Arn.) (43.9\%) and Maritime pine (P. pinaster Ait.) (12.5\%). Scattered patches of heather (Erica spp.) and rock roses (Cistus spp.) can be found. Soils are mainly acidic, although it is possible to find limestone and neutral soils.

\subsection{Database}

Sixty-six plots were installed in Pinus spp. planted stands in the study area. 34 of these plots presented predominance of $P$. sylvestris, 24 of $P$. nigra and 8 of $P$. pinaster. The main data characteristics are shown in Table I. The plots were composed of four subplots $(r=$ $15 \mathrm{~m}$ ) joined by two perpendicular transects ( $L=50 \mathrm{~m}$ for both). One of these subplots was a national forest inventory (NFI) plot. The Spanish National Forest Inventory has a spatial sampling intensity of approximately one plot per $\mathrm{km}$, and each plot has four concentric radii. The plots were selected on the systematic grid with an intensity of one plot per $2 \mathrm{~km}$ joining dominant species composition and stand minimum diameter criteria. The other three subplots were located at the three vacant extremes of the two transects. Snags were tallied in the four subplots and the logs were inventoried on the transects (Forsee, 2005).

The snag inventory was carried out through the "plotless sampling method". In this sampling method the attributes of interest are measured on the k-trees closest to a sample location (Magnussen et al., 2008). The k-trees constitute the set of sample objects for a particular sample plot. All sample plots contain the same number of $k$ trees; for this reason, it is also called the fixed-count distance method. In our 


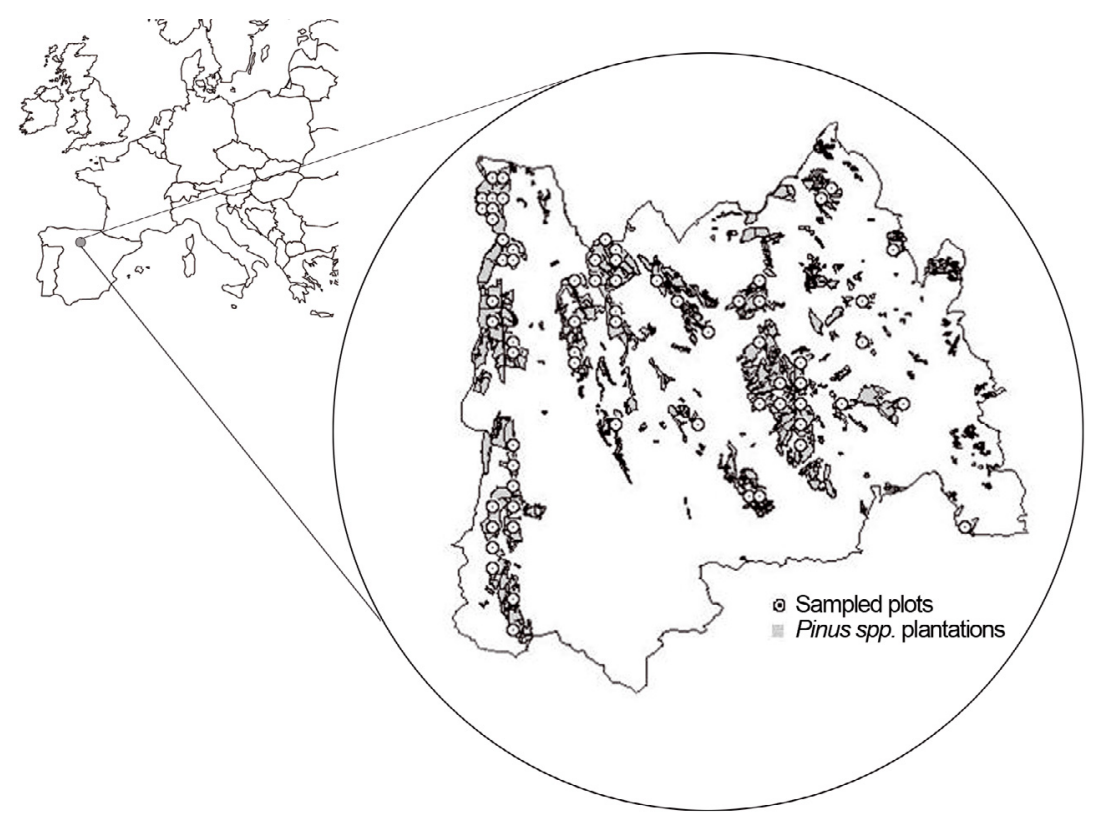

Figure 1. Location of the Pinus spp. plantations and sampled plots in the study area in Northern Spain.

case, the plotless method involved measuring the characteristics for a sample of 20 trees per subplot. Starting with the trees that were closest to the centre of the plot and moving progressively away, the condition of the trees was recorded, i.e. whether they were alive or dead. For standing dead trees (diameter at breast height $(\mathrm{dbh}) \geq 7.5 \mathrm{~cm}$ ), the following variables were recorded: species, snag height, dbh, decay class, presence of excavated cavities, and azimuth and distance to plot centre. Five decay classes were considered, from nearly sound wood (1) to the most advanced decomposition stages (5), following the criteria described by Goodburn and Lorimer (1998). The log inventory was carried out in the two perpendicular transects of $50 \mathrm{~m}$ in length that joined the four subplots. "Line intersect sampling" (LIS) was used for estimating the amount of logs. The fundamental concept of LIS is that sampling of downed woody debris occurs along transect lines. Warren and Olsen (1964) introduced the first application of the LIS technique for estimating logging residue in New Zealand. Each $\log$ is reduced to its centreline axis. A piece is included in the sample if its centreline is intersected by the transect and the number of intersections is recorded. In this inventory, logs were defined as fallen dead trees with diameter greater than $7.5 \mathrm{~cm}$, downed on the ground or suspended by one of their extremes, but with an inclination greater than $45^{\circ}$ from vertical. The following variables were measured: species, diameter at the interception point, length, decay class, inclination above the floor and signs of wildlife characteristics such as hollows or bird nests (Forsee, 2005). Five decay classes were considered following the criteria of Sollins (1982).

Snag basal area $\left(\mathrm{m}^{2}\right)$ and $\log$ volume $\left(\mathrm{m}^{3}\right)$ were calculated for each plot. The individual basal area for each tree was totalled for each plot and the values scaled up to give a basal area per hectare. Log volume was estimated through equation (1) (Warren and Olsen, 1964):

$$
V_{i}=\frac{\left(\pi^{2} \Sigma d_{i j}^{2}\right)}{8 L}
$$

where $V_{i}$ is the estimated log volume in the $i$ th plot $\left(\mathrm{m}^{3} / \mathrm{ha}\right) ; d_{i j}$ the intersection diameter of the $j$ th $\log$ in the $i$ th plot $(\mathrm{cm})$; and $L$ transect length, in our case $100 \mathrm{~m}$.

Data from the third NFI (conducted in 2003) were used to calculate different tree and stand variables, site conditions (soil texture, soil organic matter, $\mathrm{pH}$, soil type, altitude, stoniness, slope, exposure and radiation) and forest management history (harvest and thinning over the previous $15 \mathrm{y}$ ). Climate characteristics (rainfall, and maximum, mean and minimum temperature) were obtained through a digital climatic atlas (Ninyerola et al., 2005). The site index (SI) was considered by a linear combination of variables describing site productivity as dominant height $\left(H_{\mathrm{o}}\right)$, soil texture, soil organic matter, $\mathrm{pH}$, soil type, altitude, stoniness, maximum slope and exposure (Bravo and Montero, 2001). The data set (Tab. I) covers a wide basal area situation of Pinus spp. stands ranging from $5.6 \mathrm{~m}^{2} /$ ha to $39.3 \mathrm{~m}^{2} / \mathrm{ha}$. Snags were present in 20 plots, logs in 25 plots and CWD (snags and logs) was present in 33 plots.

\subsection{Statistical methods}

A two-step regression approach was used to model the presence of CWD. The first step of the two-step regression consisted of a logistic model Equation (2) for predicting the probability of CWD presence/absence in a plot, and the second step consisted of linear models Equation (3) to quantify the basal area of snags $\left(\mathrm{m}^{2} / \mathrm{ha}\right)$ and the volume of $\operatorname{logs}\left(\mathrm{m}^{3} / \mathrm{ha}\right)$. Principal Component Analysis and Discriminant Analysis were used as exploratory analyses to select the continuous variables to predict CWD presence. The variables tested were parameters that described stand development, site conditions and climate characteristics. They were $Q M D$ (quadratic mean diameter $(\mathrm{m})), H_{\mathrm{o}}$ (dominant height $\left.(\mathrm{m})\right), N$ (number of trees in the stand (trees/ha)), BA (basal area of stand $\left.\left(\mathrm{m}^{2} / \mathrm{ha}\right)\right), S$ (slope $\left.(\%)\right)$, Alt (altitude (m als)), $\operatorname{Exp}$ (exposure), $R$ (rainfall $(\mathrm{mm})), R_{\text {june }}, R_{\text {july }}$ and $R_{\text {august }}$ (rainfall for the months of June, July and August, respectively 
(mm)), MaxT (maximum temperature $\left({ }^{\circ} \mathrm{C}\right)$ ), Mean $T$ (mean temperature $\left({ }^{\circ} \mathrm{C}\right)$ ), $\operatorname{Min} T$ (minimum temperature $\left({ }^{\circ} \mathrm{C}\right)$ ), and $\operatorname{Rad}$ (radiation $\left(10 \mathrm{~kJ} /\left(\mathrm{m}^{2}\right.\right.$ day $\left.\left.\mu \mathrm{m}\right)\right)$. In the logistic model, score variable selection was carried out to choose the best model. All the previous variables were considered but the resulting logistic regression equations included only variables where the true slope associated with the variable was significantly different from zero $(p \leq 0.05)$. In the better models, the categorical variables species, soil texture, soil organic matter, $\mathrm{pH}$, soil type, stoniness, slope and thinning operations in the last $15 \mathrm{y}$ were tested to improve the model. Information obtained by applying variable selection methods was combined with the ecological reasonability of selected parameters to get the final model.

In the logistic model equation (2), $P$ is the probability of the presence of CWD, which is bound between 1 (presence) and 0 (absence), $\alpha$ is the intercept term, $\Sigma b_{i} X_{i}$, is the linear combination of parameters $b_{i}$ and independent variables $X_{i}$ and $e$ is the natural logarithm base

$$
P=\left(1+e^{-\left(\alpha+\sum b_{i} X_{i}\right)}\right)^{-1} .
$$

The goodness of fit was evaluated using the Hosmer and Lemeshow test (1989). The Proc Logistic procedure of the SAS 9.1 statistical program was used in the process (SAS Institute Inc., 2009). Receiver operating characteristic (ROC) curves for each model were used to compare the accuracy of different logistic regression models.

To quantify the abundance of snags and logs (in terms of basal area and volume, respectively) in those plots where CWD presence was predicted by the logistic model (threshold value $=0.60$ ), linear models equation (3) were used,

$$
\hat{y}=a_{0}+\sum a_{i} X_{i}
$$

where $\hat{y}$ is estimated Basal Area of snags or Volume of logs, $X_{i}$ are predictor variables (i.e., stand variables, site conditions and climate characteristics), and $a_{0}$ and $a_{i}$ are parameters to be estimated. Tested $X_{i}$ were the same variables used in the logistic regression.

The adequacy of the joint model was analysed by different parameters. The simultaneous test of the equation parameters between actual and predicted values (4) was used to know if the model was biased or not. On the other hand, the precision of the model was tested by calculating the mean of the residuals (bias, Eqs. (5) and (6)] and the mean absolute difference (mad, Eq. (7)). Finally, the efficiency of the model was tested by the determination coefficient of the two-step model (Eq. (8)) and by the ratio error for the two-step model (relation between the mean absolute difference (mad, Eq. (7)) and the mean of actual values).

The simultaneous $F$-test of the equation parameters between actual and predicted values (Eq. (4)) $\left(c_{10}=0\right.$ and $\left.c_{11}=1\right)$ is a good intuitive and reasonable test. Presumably, the intuition underlying this test is that if the model is a good one, the regression should be a $45^{\circ}$ line and demonstrate that the model is unbiased (Huang et al., 2003).

$$
\text { actual }=c_{10}+c_{11} \text { predicted }
$$

where actual is the value of snag (basal area) or log (volume) abundance observed and predicted is the value obtained by using the twostep model, while $c_{10}$ and $c_{11}$ are the parameters to be adjusted.

The precision parameter equations are:

$$
\begin{gathered}
\text { bias }=\frac{\sum(\text { actual }- \text { predicted })}{n} \\
\text { bias } \%=100 \times \frac{\sum(\text { actual }- \text { predicted }) / n}{\sum \text { predicted } / n}
\end{gathered}
$$

$$
\text { mad }=\frac{\sum \mid(\text { actual }- \text { predicted }) \mid}{n}
$$

where $n$ is the number of observations.

The determination coefficient presents the following expression:

$$
R^{2}=100 \times\left(1-\frac{S_{e}^{2}}{S_{d}^{2}}\right)
$$

where $S_{e}^{2}$ and $S_{d}^{2}$ are, respectively, the sample variance of residuals committed and the sample's variance in the dependent variable (basal area of snags or volume of logs).

Finally, to analyse the predictive capacity of the two-step model a cross-validation was carried out. The values of the prediction residuals were used to calculate the bias and the determination coefficient of actual-predicted values of the two components, snags and logs.

\section{RESULTS}

The two-step model proposed allowed us to obtain a joint model with a determination coefficient of $39.9 \%$ and $62.8 \%$ for snag and $\log$ models in the Pinus spp. stand, respectively.

\subsection{Step I. Logistic component}

The value of the Hosmer and Lemeshow test $(P>0.5817)$ for the logistic model (Tab. II) showed that there was no lack of fit. Significant independent variables were altitude ( $\mathrm{m}$ asl), minimum temperature $\left({ }^{\circ} \mathrm{C}\right)$, soil texture (clay and silt) and the presence of thinning operations. Variables for soil texture and the presence of thinning operations were placed in the model using a variable dummy (clay text $=1$ if the soil texture was clay, 0 otherwise; silt text $=1$ if the soil texture was silt, 0 otherwise; and thinning $=1$ if there was presence of thinning operations in Pinus spp. stands, 0 otherwise). Figure 2 showed the different probabilities of CWD presence on clay soils when thinning operations were carried out. For the given values of altitude ( $\mathrm{m}$ asl) and minimum temperature $\left({ }^{\circ} \mathrm{C}\right)$, the probability of CWD presence was higher in plots where thinning was carried out. The threshold value (0.60) allowed us to classify $68.2 \%$ of Pinus spp. plots correctly (sensitivity equal to $51.5 \%$ and specificity equal to $84.4 \%$ ). The area under the ROC curve in the CWD logistic model was 0.7087 .

\subsection{Step II. Linear component}

The linear model component allowed us to estimate the stand snag basal area and log volume. The pine stand linear snag component (Tab. II) showed an adjusted coefficient of determination equal to $17.5 \%$, and the linear log component (Tab. II) an adjusted coefficient of determination equal to $46.1 \%$. In the first case, the snag BA increased when June rainfall decreased, while log volume increased when stand basal area increased and when the dominant height decreased. 
Table II. CWD logistic model variables and linear components of the snag and log equations for Pinus spp. plantations in Northern Spain.

\begin{tabular}{lccc}
\hline & Estimate & Standard error & \\
\hline Logistic Component $(n=66)$ & & & $P>$ Chi-squared \\
Independent term & -43.2715 & 16.7061 & 0.0084 \\
Altitude & 2.5501 & 1.0267 & 0.0114 \\
Minimum temperature & 0.3939 & 0.1696 & 0.0183 \\
Clay Soil Texture & 4.6453 & 1.9376 & 0.0154 \\
Silt Soil Texture & 2.4439 & 0.9836 & 0.0117 \\
Thinning operations & 2.5136 & 0.7768 & 0.0011 \\
Snag Lineal Component $(n=22)$ & & & $p$-value \\
Independent term & 2.1846 & 3.4168 & 0.0199 \\
Rainfall in June & -0.0038 & 0.0412 & 0.0504 \\
Log Lineal Component $(n=22)$ & & & $p$-value \\
Independent term & 0.8821 & 1.4191 & 0.5976 \\
Basal Area & 0.2046 & 0.0507 & 0.0006 \\
Dominant height & -0.4028 & 0.1517 & 0.0190 \\
\hline
\end{tabular}

Altitude ( $\mathrm{m}$ asl), minimum temperature $\left({ }^{\circ} \mathrm{C}\right.$ ), soil texture classes (clay, silt and sandy), thinning operations in the last $15 \mathrm{y}$, rainfall in June (mm), basal area $\left(\mathrm{m}^{2} / \mathrm{ha}\right)$ and dominant height $(\mathrm{m})$.

Table III. Simultaneous test parameters and confidence intervals of regression between observed and predicted values in snag basal area and log volume.

\begin{tabular}{lccc}
\hline \multicolumn{1}{c}{ Estimate } & Confidence Interval & Standard error \\
\hline \multicolumn{2}{l}{ Lineal Component actual $=c_{10}+c_{11}$} & predicted snag basal area $(n=66)$ & \\
$c_{10}$ & $-2.5028^{-16}$ & $(-0.0491,0.0491)$ & 0.0246 \\
$c_{11}$ & 1.0000 & $(0.6893,1.3107)$ & 0.1555 \\
Lineal Component actual $=c_{10}+c_{11}$ & predicted log volume $(n=66)$ & \\
$c_{10}$ & 0.0070 & $(-0.2152,0.2292)$ & 0.1113 \\
$c_{11}$ & 1.0054 & $(0.8156,1.1953)$ & 0.0951 \\
\hline
\end{tabular}

\section{Logistic model}

Thinned Pinus spp. plantations on clayey soils prob $=1 /(1+\exp (-(-43.2715+2.5501 *$ Altitude $+3.9395 * \operatorname{MinT}+4.6453+2.5136)))$

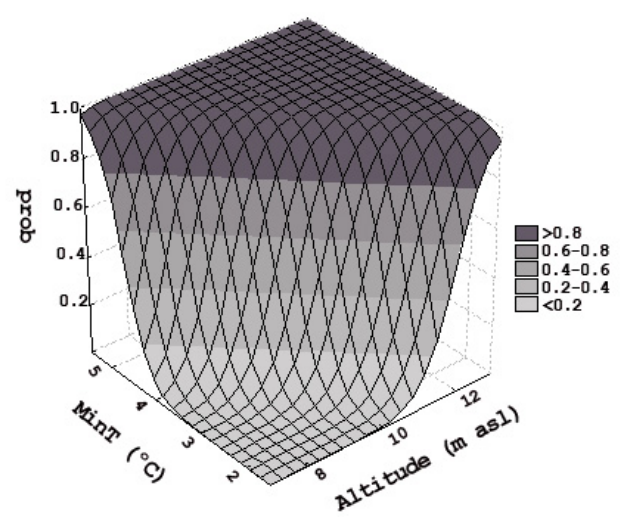

Figure 2. Probability of the presence of CWD in the case of thinned stands and clay soils.

\subsection{Joint model validation}

The regression line between actual and predicted values (Tab. III) showed that the independent term was not significantly different from zero and the slope was not significantly different from one in both cases. The simultaneous test of the parameters of the equation between actual and predicted values $(P<0.0001)$ indicated that the joint models showed no lack of fit in snag basal area and log volume. On the other hand, the absolute bias for snags and logs was very low $\left(-0.0024 \mathrm{~m}^{2} /\right.$ ha and $0 \mathrm{~m}^{3} /$ ha, respectively). In relative terms, the snag and log bias was low in all cases: $2.9 \%$ in snags and $0 \%$ in logs. Also, the mean absolute differences were 0.07 and 0.37 for snags and logs. Thus, the joint model did not show model bias or lack of accuracy. Finally, the proposed twostep model achieved joint model accuracy equal to $39.9 \%$ and $62.8 \%$ for snags and logs, respectively. On the other hand, the ratio error of the two-step model (mean absolute difference divided by the mean of actual values) was $91.3 \%$ for snag basal area and $71.4 \%$ for log volume. Graphical analyses were carried out to analyse this coefficient in different categories of actual values in snag basal area and log volume (Fig. 3). These graphs showed that the ratio error for the two-step model increased when the value of the actual data decreased. This situation was more important when the basal area of snags or the volume of logs were below $0.1 \mathrm{~m}^{2} /$ ha or $1 \mathrm{~m}^{3} /$ ha. The high proportion of zero value plots (no snags or no down woody debris in the plot) greatly determined the final model efficiency.

The results of the cross-validation approach determined the stability of the model. They showed good model accuracy in 

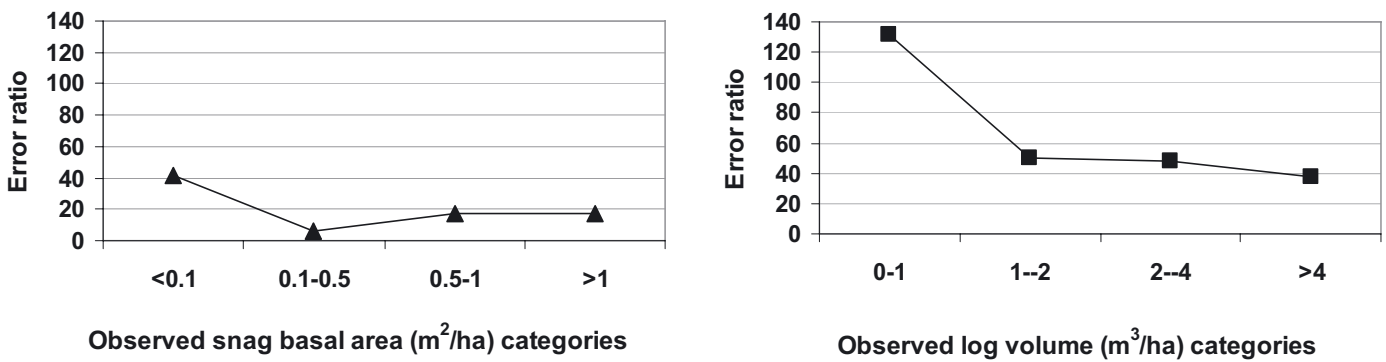

Figure 3. Error ratio of the two-step model by the different observed value categories in log and snag components.

the two components of CWD: snags $\left(R^{2}=38.7 \%\right.$ and bias $=$ $-0.0056)$ and $\operatorname{logs}\left(R^{2}=62.0 \%\right.$ and bias $\left.=-0.0036\right)$.

\section{DISCUSSION}

The pine plantations studied range from 30 to $60 \mathrm{y}$ old and are managed for wood production. Periodically, dead and decayed trees have been harvested, maintaining only an average of from 1 to 10 snags per 5 hectares, in accordance with the forestry management guidelines in the Castilla y Leon region (Northern Spain). To model different binary events in forest research, a logistic equation has been used alone (Bravo-Oviedo et al., 2006) or combined with a linear model in a two-step approach (Álvarez et al., 2004; Bravo et al., 2008). The equations obtained in this study allowed us to model CWD presence and quantify snags and logs in Mediterranean Pinus spp. plantations. The Pinus spp. plantation CWD fitted model predicted CWD presence by using altitude, minimum temperature, soil texture and the presence of thinning operations over the last $15 \mathrm{y}$. Thinning carried out in our study area increased CWD presence in the stand. More direct radiation, non-extraction of logs lacking commercial value and possible damage during the thinning operations could increase the likelihood of snag trees, pieces of broken snag trees or snags falling over with time that remained on the ground (logs) (Ranius et al., 2003). The effects of management on CWD dynamics have previously been studied (Green and Peterken, 1997; Siitonen et al., 2000). Green and Peterken showed that conversion of former coppices to high forest allows deadwood volume to increase. In our case, the amount of CWD increased in harvested plots. These results are consistent with findings in other managed forests in Europe (Brin et al., 2008). In this sense, forest management guidelines play an important role in the amount of CWD in the region because, during harvesting, some of the harvested trees could be left in the stand and because thinning operations could be carried out predictably and regularly. On the other hand, plots at high altitude or plots on clay soils showed a higher probability of CWD presence. Higher altitudes would mean worse conditions for tree growth and stand productivity (Holmgren, 1994). Soil coarse texture may also influence tree mortality because it could affect soil moisture (McHugh and Kolb, 2003), root penetration, tree vigour and site index (Bravo et al., 2001). In this area, higher clay contents were found at deeper horizons of the soil profile (Forsee,
2005) because an argic horizon is present (WRB, 2006). This fact may contribute to tree mortality in dry conditions because it creates soil compaction and limitation of the spatial distribution of roots. Finally, minimum temperature was also selected to explain the CWD presence probability. Mediterranean forest growth is constrained by drought and high temperatures during summer. As the climate forecast for the next decades in the Mediterranean basin indicates a higher temperature situation (IPCC, 2007), drought could increase, creating stressful periods and therefore tree mortality (Bréda et al., 2006; Martinez-Vilalta et al., 2002).

Stand variables were not significant for predicting CWD presence in Pinus spp. plantations. These variables (Number of trees/ha $(N)$, Basal area (BA), Site index (SI), etc.) influence the amount of CWD because only stems $>10 \mathrm{~cm}$ in diameter are generated during the intermediate and later parts of the rotation period in managed forest (Ranius et al., 2003). In this sense, a limitation of this study was the strong dependence on available studied young Pinus spp. plantations, without different stand development stages. Pine plantation stand conditions were so homogenous that they did not allow us to relate CWD to stand and silviculture variables. Further studies, including a wide array of forest stand characteristics (density, age, etc.), may help to find a relationship between CWD and stand variables and define an appropriate forest structure to increase regional CWD.

The linear model allowed us to quantify snag and log abundance, showing the relationship between snag basal area and June rainfall $\left(R^{2}=17.5 \%\right)$ and between log volume and basal area and dominant height $\left(R^{2}=46.1 \%\right)$. Climatic variables were again selected in the snag model. This is very important in simulating different scenarios under climate change circumstances where it is suggested that there will be changes in precipitation regimes in Western Europe. Severe precipitation deficits may cause mortality of roots or twigs and could ultimately lead to tree death, increasing snag amount (Bréda et al., 2006). In contrast, log quantity is higher in stands with greater basal area and low productivity, because the competition in these sites is higher.

The two-step model emphasised the importance of forest management in CWD presence in this region and allowed us to combine knowledge (understanding and data) and prediction of system dynamics. Unmanaged forests in Spain are scarce because of centuries of forestry practices. Intensive management activities have led to timber removal and woody 
material loss for centuries. However, Mediterranean forests currently present a low silviculture activity because of the harvest economic yield. In this sense, the two-step model can provide objective forecasts and information for exploring management options and silvicultural alternatives for sustainable forest management. The objective of this study was to incorporate a new model into the understanding of CWD dynamics. This kind of model is scarce for Mediterranean forest stands. One reason could be the limited amount of CWD in managed Mediterranean forest ecosystems (Brin et al., 2008; Montes and Cañellas, 2006). Another reason could be the difficulty of modelling these stochastic variables. CWD stores in forest regions are difficult to assess because they vary significantly over succession and do not necessarily parallel the dynamics of live biomass (Krankina et al., 2001). CWD is highly variable in space and time. The lack of CWD in a large number of plots determined the logistic model prediction, linear model precision and final model accuracy. For this reason, it is important to develop further research on binary event modelling, as well as increasing sample size and its precision to improve model accuracy and efficiency. Data on the amount of dead wood are available for different types of temperate forest, but modelling is a step forward for dead wood management. Models may help us to understand the spatial amount and temporal dynamics of dead wood or the effects of various silvicultural strategies, such as intermediate thinning, as in this case. Predicting and quantifying dead wood in the ecosystems is the first step in understanding CWD dynamics. The results of this empirical study allowed us to approximate the amount of CWD in pine plantations in a Mediterranean area in Spain and can serve as the first milestone in developing useful tools for practical forestry. Dead wood management (size, amount, density, decomposition status and its distribution throughout the forest) is currently one of the most important questions to be resolved for forest management in the context of sustainability and biodiversity conservation. More detailed CWD studies can help to establish baselines and guidelines in different forest types.

Acknowledgements: This work has been made possible through research under the projects -"Sustainable Forest management: a network of pilot zones for operational implementation (FORSEE)" financed by the European Union (FEDER) and "Restoration and Forest management (PSS-310000-2009-22) financed by the Spanish Science Ministry. The authors thank Cinnamon Nolan for her helpful English review and the two anonymous referees for their valuable comments on the manuscript.

\section{REFERENCES}

Álvarez González J.G., Castedo Dorado F., Ruiz González A.D., López Sánchez C.A., and von Gadow K., 2004. A two-step mortality model for even-aged stands of Pinus radiata D. Don in Galicia (Northwestern Spain). Ann. For. Sci. 61: 441-450.

Barclay H.J. and Layton C.R., 1990. Growth and mortality in managed Douglas fir: relation to competition index. For. Ecol. Manage. 36: 187-204.

Bravo F. and Montero G., 2001. Site index estimation in Scots pine (Pinus sylvestris L.) stands in the High Ebro Basin (Northern Spain) using soil attributes. Forestry 74: 395-406.
Bravo F., Pando V., Ordóñez C., and Lizarralde I., 2008. Modelling ingrowth in Mediterranean pine forests: A case study from scots pine (Pinus sylvestris L.) and Mediterranean maritime pine (Pinus pinaster Ait.) stands in Spain. Investig. Agrar. Sist. Recur. For. 17: 250-260.

Bravo-Oviedo A., Sterba H., del Río M., and Bravo F., 2006. Competition induced mortality for Mediterranean P. pinaster Ait. and P. sylvestris L. For. Ecol. Manage. 222: 88-98.

Bréda N., Huc R., Granier A., and Dreyer E., 2006. Temperate forest trees and stands under severe drought:a review of ecophysiological responses, adaptation processes and long-term onsequences. Ann. For. Sci. 63: 625-644.

Brin A., Meredieu C., Piou D., Brustel H., and Jactel H., 2008. Changes in quantitative patterns of dead wood in maritime pine plantations over time. For. Ecol. Manage. 256: 913-921.

Eid T. and Oyen B.H., 2003. Models for prediction of mortality in evenaged forest. Scand. J. For. Res. 18: 64-77.

Forsee, 2005. Proyecto FORSEE (20) INTERREG III B Espacio atlántico: http://www.iefc.net/index.php?affiche_page=projet_FORSEE. Last access on 16th December (2009).

Goodburn J.M. and Lorimer C.G., 1998. Cavity trees and coarse woody debris in old-growth and managed northern hardwood forests in Wisconsin and Michigan. Can. J. For. Res. 28: 427-438.

Green P. and Peterken G.F., 1997. Variation in the amount of dead wood in woodlands of the Lower Wye Valley, UK, in relation to the intensity of management. For. Ecol. Manage. 98: 229-228.

Hamilton D.A. and Brickell J.E., 1983. Modelling methods for a twostage system with continuous responses. Can. J. For. Res. 13: 11171121.

Harmon M.E., Franklin J.F., Swanson F.J., Sollins P., Gregory S.V., Lattin J.D., Anderson N.H., Cline S.P., Aumen N.G., Sedell J.R., Lienkaemper G.W., Cromack K. Jr., and Cummins K.W., 1986. Ecology of coarse woody debris in temperate ecosystems. Adv. Ecol. Res. 15: 133-302.

Harmon M.E. and Chen H., 1991. Coarse woody debris in two old-growth ecosystems. Comparing a deciduous forest in China and a conifer forests in Oregon. BioScience 41: 604-610.

Holmgren P., 1994. Topographic and geochemical influence on the forest site quality, with respect on the forest site quality, with respect to Pinus sylvestris and Picea abies in Sweden. Scand. J. For. Res. 9: 75-82.

Hosmer D.W. and Lemeshow S., 1989. Applied Logistic Regression, John Wiley and Sons, New York, $37 \mathrm{p}$.

Huang S., Yang Y., and Wang Y., 2003. A critical look at procedures for validating growth and yield models. In: Amaro A., Reed D. and Soares P. (Eds.), Modelling Forest Systems, Wallingford: CABI Publishing, pp. 271-293.

IPCC, 2007. Fourth Assessment Report of the Intergovernmental Panel on Climate Change. Cambridge University Press, Cambridge, United Kingdom and New York, NY, USA.

Köster K., Jôgiste K., Tukia H., Niklasson M., and Möls T., 2005. Variation and ecological characteristics of coarse woody debris in Lahemaa and Karula National Parks, Estonia. Scand. J. For. Res. 20 (Suppl 6): 102-111.

Krankina O.N., Treyfeld R.F., Harmon ME., Spycher G., and Povarov E.D., 2001. Coarse woody debris in the forest of the St. Petersburg region, Russia. Ecol. Bull. 49: 93-104.

Linder O., Elfving B., and Zackrisson O., 1997. Stand structure and successional trends in virgin boreal forest reserves in Sweden. For. Ecol. Manage. 98: 17-33.

Magnussen S., Kleinn C., and Picard N., 2008. Two new density estimators for distance sampling. Eur. J. For. Res. 127: 213-224. 
Martínez-Vilalta J., Piñol J., and Beven K., 2002. A hydraulic model to predict drought-induced mortality in woody plants: an application to climate change in the Mediterranean, Ecol. Model. 155: 127-147.

McComn W. and Lindenmayer D., 1999. Dying, dead, and down trees. In: Malcon L. and Hunter J.R. (Eds.), Maintaining biodiversity in forest ecosystems, Cambridge University Press, pp. 335-372.

McHugh C.W. and Kolb T.E., 2003. Ponderosa pine mortality following fire in northern Arizona. Int. J. Wildl Fire 12: 7-22.

Mellen K. and Ager A., 2002. A coarse wood dynamics model for the Western Cascades. USDA Forest Service Gen. Tech. Rep. PSWGTR-181.

Montes F. and Cañellas I., 2006. Modelling coarse woody debris dynamics in even-aged Scots pine forests. For. Ecol. Manage. 221: 220-232.

Ninyerola M., Pons X., and Rour J.M., 2005. Atlas climático digital de la Península Ibérica. Metodología y aplicaciones en bioclimatología o geobotánica. Universidad Autónoma de Barcelona, Bellaterra.

Ranius T., Kindvall O., Kruys N., and Jonsson B.G., 2003. Modelling dead wood in Norway spruce stands subject to different management regimes. For. Ecol. Manage. 182: 13-29.
Sas Institute Inc. 2009. SAS/STATTM User's Guide, Relase 9.1, Cary, N.C, USA.

Siitonen J., Martikainen P., Punttila P., and Rauh J., 2000. Coarse woody debris and stand characteristics in mature managed and old-growth boreal mesic forests in southern Finland. For. Ecol. Manage. 128: $211-225$.

Sollins P., 1982. Input and decay of coarse woody debris in coniferous stands in western Oregon and Washington. Can. J. For. Res. 12: $18-28$.

Spies T.A., Franklin J.F., and Thomas T.B., 1988. Coarse woody debris in Douglas-fir forests of western Oregon and Washington. Ecology 69: 1689-1702.

Warren W.G. and Olsen P.F., 1964. A line-intersect technique for assessing logging waste. For. Sci. 10: 267-276.

Woollons R.C., 1998. Even-aged stand mortality estimation through a two-step regression process. For. Ecol. Manage. 105: 189-195.

WRB, 2006. World reference base for soil resources. World Soil Resources Reports, No. 103, FAO, Rome, 145 p. 